\title{
Motility mutants of Vibrio cholerae 01 have reduced adherence in vitro to human small intestinal epithelial cells as demonstrated by ELISA
}

\author{
Tatyana Postnova, ${ }^{1}$ Oscar G. Gómez-Duarte ${ }^{2} \dagger$ \\ and Kathleen Richardson ${ }^{1,2} \ddagger$ \\ Author for correspondence: Kathleen Richardson. Tel: + 1503725 3855. Fax: + 15037253888.
e-mail: b7kr@odin.cc.pdx.edu
}

1 Biosciences Division, General Atomics, PO Box 85608, San Diego, CA 92186-9784, USA

2 Department of Microbiology and Immunology, Oregon Health Sciences University, 3181 SW Sam Jackson Park Road, Portland, OR 97201 3098, USA

\begin{abstract}
Vibrio cholerae must colonize the human small intestine to cause diarrhoeal disease. V. cholerae strains N16961 (EI Tor, Inaba) and 395 (classical, Ogawa) adhered to the epithelial cell surface and the mucus layer of isolated human small intestinal epithelial cells. They adhered specifically to the mucosa and apical membrane in thin sections of small intestine. No binding to the basolateral membrane of dissected epithelial tissue or to intracellular components of the epithelial cells was observed by either light or indirect immunofluorescence microscopy. Based on these results, a modified ELISA was developed to quantitatively study adherence of $\boldsymbol{V}$. cholerae to human small intestinal epithelial cells. The assay used homogenized human small intestinal mucosal tissue as the substrate for binding. Treatment of the epithelial cell homogenate with 2-mercaptoethanol to disrupt protein and glycoprotein secondary structure inhibited the binding of $V$. cholerae strains, suggesting that binding was to specific receptors. Several $V$. cholerae strains and mutants from both biotypes were tested for adherence in the modified ELISA. Wild-type strains of both biotypes and non-enterotoxigenic strains, which were known to colonize humans, adhered. $v$. cholerae mutants defective in motility, flagellar structure or chemotaxis, which were known to exhibit reduced colonization in animal models, exhibited decreased adherence. The specificity of the assay and its ability to quantify binding should facilitate identification and the study of adherence factors involved in the colonization of human small intestinal epithelial cells by $V$. cholerae.
\end{abstract}

Keywords: Vibrio cholerae adherence, human small intestinal tissue, quantitative ELISA, motility, flagellar and chemotaxis mutants

\section{INTRODUCTION}

Cholera is an infectious diarrhoeal disease caused by Vibrio cbolerae, a Gram-negative curved rod. The disease is transmitted by ingestion of contaminated water (Levine et al., 1982) or food (Blake et al., 1980) and is characterized by an acute severe and dehydrating diarrhoea (Levine $\&$ Edelman, 1979). $V$. cholerae attaches and grows on the

†Present address: Max-Planck-Institut für Biologie, Abt. Infektionsbiologie, Spemannstrasse 34, D 72076 Tubingen, Germany.

$\ddagger$ Present address: Biology Department, Portland State University, PO Box 751, Portland, OR 97207-0751, USA.

Abbreviation: OMPs, outer-membrane proteins. surface of the small intestine, where expression of a potent enterotoxin, cholera toxin (Gill, 1977), activates adenylate cyclase accelerating cyclic AMP pathways, leading to net secretion of electrolyte and water into the gut lumen.

The colonization process is essential to the pathogenesis of cholera, as strains which are unable to colonize the gut are also unable to cause disease in volunteers (Srivastava et al., 1980). Despite much research into the pathogenesis of cholera, the factors required for colonization of the gut are only just being described and studied. To colonize a mucosal surface, bacteria must progress sequentially through at least four different steps: (i) make contact with the mucosal surface; (ii) penetrate the mucus layer; (iii) adhere to the epithelial cell surface; and (iv) multiply 
(Freter \& Jones, 1983). Bacteria must also overcome a number of non-specific host defence mechanisms. Two non-specific defence mechanisms, small intestine peristalsis and the mucus layer coating the small intestine, apparently work together to accomplish this task. Colonization, therefore, seems to be multifactorial. Numerous surface factors have been implicated in adhesion to the mucosa of the proximal small intestinal epithelial cells (Sack, 1992), including LPS (Chitnis et al., 1982), various haemagglutinins (Finkelstein et al., 1992; Franzon et al., 1993), toxin-coregulated pilus in $V$. cholerae of classical biotype (Herrington et al., 1988; Sun et al., 1990) and several outer-membrane proteins (OMPs) (Kelley \& Parker, 1981; Singh et al., 1994; Sperandio et al., 1995). Freter et al. (1981) have shown that motile $V$. cholerae cells direct themselves to the mucosal surface in response to chemotaxis. Others have demonstrated that non-motile, fully enterotoxigenic mutants exhibit notably diminished virulence (Guentzel \& Berry, 1975; Teppema et al., 1987). We have observed that non-motile El Tor and classical $V$. sholerae strains do not colonize rabbits (Richardson, 1991).

Both in vivo and in vitro systems have been used to study colonization of the small intestine by $V$. cholerae (Richardson, 1994). In vivo systems include the adult-rabbit ligated gut model (De \& Chatterjee, 1953), removable intestinal tie adult rabbit diarrhoea model (Spira et al., 1981), oral inoculation of suckling mice (Baselski et al., 1977) and oral inoculation of volunteers (Levine et al., 1983). These studies, however, have limitations. Firstly, the number of strains to be tested in each experiment is very small. Secondly, except for the limited studies in human volunteers, none of these animal models is a natural host of $V$. cholerae.

Many in vitro models using isolated brush border membranes and intestinal tissue sections from rabbits and mice have been developed to test adherence of $V$. cholerae strains to epithelial cells (Jones \& Freter, 1976; Jones et al., 1976; Attridge \& Rowley, 1983). It is doubtful, however, that intestinal tissue from these herbivorous animals can accurately represent human small intestine. Epithelial cell lines such as HeLa, HEp-2, Caco-2 and Henle 407 have proven useful in evaluating specific mutants (Sperandio et al., 1995) but are limited in their ability to mimic in vivo colonization since these cells exhibit few of the characteristics of in vivo primary intestinal epithelial cells. Recently, a continuous cell line of human intestinal epithelial cells (Finkelstein $e t$ al., 1992) has been used to evaluate $V$. cholerae adherence. Continuous cell lines differ inherently from in vivo differentiated tissue. Yamamoto \& Yokota (1988) used in vitro adherence to human small intestine and scanning electron microscopy to evaluate the role of the cell-associated haemagglutinin of $V$. cholerae $\mathrm{O} 1$ in adherence. These in vitro assays frequently involve microscopic observation and counting of the adherent vibrios manually, limiting their use in the analysis of numerous different isolates or screening mutagenized bacterial strains.

Here we report on a new adherence assay using homogenized human small intestinal tissue in a modified
ELISA. The binding properties of $V$. cholerae to mucosal homogenate were consistent with observed binding to intact epithelial cells. The assay was able to detect, as well as quantify, binding of vibrios to human small intestine. Wild-type strains of both $V$. cholerae biotypes and nonenterotoxigenic strains adhered. $V$. cholerae mutants defective in motility and flagellar structure, which were known to exhibit reduced colonization in animal models, exhibited decreased adherence, as did chemotaxis mutants. The specificity of the assay and its ability to quantify binding should facilitate identification and study of adherence factors involved in the colonization of human small intestinal epithelial cells by $V$. cholerae.

\section{METHODS}

Bacterial strains and media. The Escbericbia coli and $V$. cholerae strains used are listed in Table 1. The E. coli strain NF5 was isolated from the stool of a healthy adult on MacConkey agar (Difco) and identified using the Biolog identification system. For the adherence assay, bacteria were grown on freshly prepared Brain Heart Infusion (BHI) broth (Difco) containing $1 \%(\mathrm{w} / \mathrm{v})$ Bacto agar (Difco). To examine the effect of growth media on adherence, bacteria were grown in broth and on agar plates of the following media: minimal A medium containing $0 \cdot 2 \%$ (w/v) glucose (Miller, 1972); LB medium (Miller, 1972); LB medium containing $0.2 \%(\mathrm{w} / \mathrm{v})$ glucose; peptone medium (Yang et al., 1977); and peptone/beef extract medium (Parker \& Romig, 1972). Bacteria were grown overnight at $35^{\circ} \mathrm{C}$, harvested from plates to Krebs/Ringer/Tris buffer (KRTB; Jones $e t a l ., 1976$ ) and washed twice in KRTB by centrifugation at $3000 \mathrm{~g}$ for $10 \mathrm{~min}$ at $4{ }^{\circ} \mathrm{C}$. The bacteria were resuspended in $\mathrm{KRTB}$ to give an $\mathrm{OD}_{600}$ of $1 \cdot 0$. Bacterial suspensions were kept on ice until used.

Antibodies and ELISA reagents. Antibody to OMP of $V$. cholerae strain KR26 (a non-motile aflagellate mutant of strain N16961) was obtained by three weekly subcutaneous immunizations of $2 \mathrm{~kg}$ New Zealand White female rabbits. OMP (150 mg protein), isolated by the lithium chloride method (Sears $e t$ al., 1984), was resuspended in an equal volume of either complete Freund's adjuvant (primary injection) or incomplete Freund's adjuvant (boosters), in a final volume of $200 \mu \mathrm{l}$. Antibodies to whole cells of $V$. cholerae strains 395 and KR202 and E. coli strain HB101 were obtained as described above except that bacterial cells ( $5 \mathrm{mg}$ protein $\mathrm{ml}^{-1}$ ) were boiled for $5 \mathrm{~min}$, the initial subcutaneous injection was in a total volume of $500 \mu \mathrm{l}$ and the subsequent two immunizations were in a total volume of $300 \mu \mathrm{l}$.

The secondary antibody, a peroxidase-conjugated goat antirabbit immunoglobulin, was purchased from either Organon Teknica-Cappel or Jackson ImmunoResearch Labs, and used at a dilution of $1: 1000$ or $1: 5000$, respectively, as determined by checkerboard assay. Bound antibody was assayed with ophenylenediamine (Sigma) resuspended in peroxidase conjugate substrate buffer $\left(50 \mathrm{mM} \mathrm{Na}_{2} \mathrm{HPO}_{4}, 25 \mathrm{mM}\right.$ citric acid and $0.4 \mu \mathrm{l}$ $30 \%, \mathrm{v} / \mathrm{v}, \mathrm{H}_{2} \mathrm{O}_{2} \mathrm{ml}^{-1}$ ).

Isolation and processing of human small intestine tissue. Human small intestinal tissue was obtained after small intestine resections performed during scheduled surgeries at the Oregon Health Sciences University or Providence Hospital, in Portland, OR, USA, or as normal tissue sections from the Pacific Northwest Transplant Bank at Oregon Health Sciences University. Only morphologically normal tissue was used for the experiments. Tissue was kept in PBS containing EDTA (0.14 M 
Table 1. E. coli and V. cholerae strains used

\begin{tabular}{|c|c|c|}
\hline Strain & Description or genotype & Source or reference \\
\hline \multicolumn{3}{|c|}{ V. cholerae $\mathrm{O} 1$} \\
\hline \multicolumn{3}{|c|}{ El Tor biotype } \\
\hline N16961 & Serotype Inaba, from patient & $\mathrm{CVD}^{*}$ \\
\hline KR518 & $\begin{array}{l}\text { Serotype Inaba, motile prototroph Tn } 10 \text { mini-Kan insertion mutant, } \\
\text { derivative of strain N1696 }\end{array}$ & K. Richardson \\
\hline KR26 & $\begin{array}{l}\text { Serotype Inaba, aflagellate Tn10 mini-Kan insertion mutant, derivative of } \\
\text { strain N16961 }\end{array}$ & Richardson et al. (1990) \\
\hline KR31 & $\begin{array}{l}\text { Serotype Inaba, non-motile Tn10 mini-Kan insertion mutant, derivative of } \\
\text { strain N16961 }\end{array}$ & Richardson et al. (1990) \\
\hline SB001 & $\begin{array}{l}\text { Serotype Inaba, haemagglutinin-negative, cholera-toxin-negative mutant, } \\
\text { derivative of strain N16961 }\end{array}$ & Finn et al. (1987) \\
\hline $\mathrm{C} 5$ & Serotype Ogawa, field isolate from Indonesia & Teppema et al. (1987) \\
\hline $1074-78$ & Serotype Ogawa, non-enterotoxigenic strain & Levine et al. (1982) \\
\hline $1196-78$ & Serotype Ogawa, non-enterotoxigenic strain & Levine et al. (1982) \\
\hline \multicolumn{3}{|c|}{ Classical biotype } \\
\hline 395 & Serotype Ogawa, from patient & CVD \\
\hline 395.2 & Serotype Ogawa, neuraminidase-negative Tn10 mini-Kan insertion mutant & CVD \\
\hline KR1 & $\begin{array}{l}\text { Serotype Ogawa, aflagellate, sheathed, Tn } 10 \text { mini-Kan insertion mutant, } \\
\text { derivative of strain } 395\end{array}$ & Richardson et al. (1990) \\
\hline KR201 & $\begin{array}{l}\text { Serotype Ogawa, spontaneous non-motile flagellate mutant, derivative of } \\
\text { strain } 395\end{array}$ & K. Richardson \\
\hline KR202 & $\begin{array}{l}\text { Serotype Ogawa, spontaneous non-motile aflagellate mutant, derivative of } \\
\text { strain } 395\end{array}$ & K. Richardson \\
\hline $\mathrm{C} 21$ & $\begin{array}{l}\text { Serotype Ogawa, field isolate from Dacca, spontaneous non-motile aflagellate } \\
\text { mutant with no haemagglutinating activity }\end{array}$ & Teppema et al. (1987) \\
\hline \multicolumn{3}{|l|}{ E. coli } \\
\hline NF5 & Normal flora, motile isolate from volunteer & K. Richardson \\
\hline HS & Normal flora, non-motile isolate from volunteer & CVD \\
\hline LE392 & $\mathrm{F}^{-}$bsdR $514\left(\mathrm{r}_{\mathrm{K}}^{-} \mathrm{m}_{\mathrm{K}}^{-}\right)$galK2 galT22 lacY1 metB1 trpR55 supE44 supF58 & Murray et al. (1977) \\
\hline HB101 & $\begin{array}{l}\sup E 44 \text { bsdS } 20\left(\mathrm{r}_{\mathrm{B}}^{-} \mathrm{m}_{\mathrm{B}}^{-}\right) \operatorname{rec} A 13 \text { ara-14 pro A2 lacY1 galK2 rpsL20 xyl-5 } \\
m t l-1\end{array}$ & $\begin{array}{l}\text { Boyer \& Rouland-Dussoix } \\
\text { (1969) }\end{array}$ \\
\hline
\end{tabular}

* Obtained from the Center for Vaccine Development (CVD), Baltimore, MD, USA.

$\mathrm{NaCl}, 1.5 \mathrm{mM} \mathrm{KH}_{2} \mathrm{PO}_{4}, 8.1 \mathrm{mM} \mathrm{Na}_{2} \mathrm{HPO}_{4}, 2.7 \mathrm{mM} \mathrm{KCl}$ and $10 \mathrm{mM}$ EDTA; PBS-EDTA) at $4{ }^{\circ} \mathrm{C}$ immediately after small intestine resection. The length of time the tissue was held at $4{ }^{\circ} \mathrm{C}$ until processed or frozen at -20 or $-70^{\circ} \mathrm{C}$ for later use or both was logged for all tissues. None of the tissue used in these experiments was held longer than $12 \mathrm{~h}$ at $4{ }^{\circ} \mathrm{C}$ prior to use or freezing.

The use of human small intestinal tissue was approved by the Human Subjects Committee of the University and was exempt under the regulations of the United States Department of Health and Human Services, since information was recorded in such a manner that subjects could not be identified, directly or through identifiers linked to the subjects by the investigator.

The mucosal layer was dissected away from connective tissue and the muscular layer, rinsed three times with PBS and cut into three pieces for: (i) epithelial cell isolation; (ii) tissue thin sectioning; and (iii) homogenate preparation.

(i) Isolation of epithelial cells. The apical portion of the mucosal layer was scraped against a sterile metallic screen or, for large pieces of tissue, scraped with a glass slide. The epithelial cells were recovered in a tube containing PBS-EDTA and either used immediately or stored frozen at $-70^{\circ} \mathrm{C}$. Epithelial cells were washed twice by resuspending the cells in $5 \mathrm{ml}$ PBS and centrifuging for $5 \mathrm{~min}$ at $500 \mathrm{~g}$ at $4{ }^{\circ} \mathrm{C}$. The cells were gently resuspended in PBS-EDTA and diluted to give a concentration of approximately $10^{6}$ cells $\mathrm{ml}^{-1}$. Cells were kept on ice until used. When frozen cells were used, cells were thawed on ice, then processed as described.

(ii) Mucosal tissue sections. Sectioning of tissue was done by embedding pieces of small intestine in OCT compound containing $20 \%(\mathrm{v} / \mathrm{v})$ glycerol (ultrapure; United States Biochemical), freezing with liquid nitrogen and sectioning immediately or storing at $-70^{\circ} \mathrm{C}$. Sectioned tissue on slides was stored at $-70^{\circ} \mathrm{C}$.

(iii) Human small intestine homogenate. Pieces of mucosal layer (approx. $2 \mathrm{~cm}^{2}$ ) were stored at $-70{ }^{\circ} \mathrm{C}$ or used immediately. Homogenate was obtained as follows. The tissue was placed in $3 \mathrm{ml}$ PBS-EDTA, blended in an Omni-mixer (Ivan Sorvall) for 5 min at half-speed setting at $4{ }^{\circ} \mathrm{C}$ and an equal volume of PBSEDTA was added to the homogenate before centrifugation for $10 \mathrm{~min}$ at $2500 \mathrm{~g}$ at $4{ }^{\circ} \mathrm{C}$ to remove connective tissue. The supernatant fraction was recovered, protein concentration was determined by the Lowry method and $500 \mu \mathrm{l}$ aliquots or aliquots containing $2 \mathrm{mg}$ protein were stored in microfuge tubes at 
$-20^{\circ} \mathrm{C}$ or kept on ice for immediate use. Homogenate was stored at $-20^{\circ} \mathrm{C}$ for no longer than 3 months, and at $-180^{\circ} \mathrm{C}$ for longer term storage. By light microscopy, the homogenate in the supernatant fraction contained fragments of epithelial cells and cytosol and few distinguishable intact cells.

\section{Adherence assays}

(i) Epithelial cell adherence assay. The epithelial cell suspension $(40 \mu l)$ was spread gently on a glass slide, allowed to dry, and the cells were fixed by a short exposure to a flame. The bacterial cell suspension $(200 \mu \mathrm{l})$ in $\mathrm{KR}^{\prime} \mathrm{TB}\left(\mathrm{OD}_{600}\right.$ of $\left.1 \cdot 0\right)$ was spread on the fixed cells and the slides were incubated at $35^{\circ} \mathrm{C}$ for $15 \mathrm{~min}$ in a humid chamber. The reaction was stopped by washing the slides three times with $10 \mathrm{ml}$ PBS. After drying at room temperature, the slides were stained with Gram stain, Giemsa or haematoxylin-eosin and examined by light microscopy to determine the numbers of bacteria associated with the epithelial cells.

(ii) Mucosal tissue section adherence assay. Tissue sections attached to slides were reacted with bacteria as previously described for the epithelial cell adherence assay, except that adherent bacteria were fixed to the slide by immersion in Omnifix II (An-Con Genetics) for $5 \mathrm{~min}$. For examination by light microscopy, the slide was immediately stained with haematoxylin-eosin and mounted using Permount (Fisher Scientific). To observe bacterial adherence by indirect immunofluorescence, primary antibody diluted in PBS containing $1 \%(\mathrm{w} / \mathrm{v})$ BSA (PBS-BSA) was placed on the sections and incubated at $35^{\circ} \mathrm{C}$ for $15 \mathrm{~min}$. Primary antiserum at various dilutions was reacted with bacteria fixed to glass slides to determine the optimal dilution of antiserum to use. Rabbit anti- $V$. cholerae strain 395 whole cell antibody at a dilution of $1: 1000$ was used to visualize $V$. cholerae strains 395, KR31 and C5. For $V$. cholerae strain N16961, rabbit anti-KR26 OMP antibody at a dilution of 1:500 was used. Rabbit anti-HB101 whole cell antibody at a dilution of $1: 50$ was used to visualize E. coli strain HS. Slides were washed with PBS containing $0.05 \%(\mathrm{v} / \mathrm{v})$ Tween 20 (PBS-Tween) and incubated at $35^{\circ} \mathrm{C}$ for $15 \mathrm{~min}$ with goat anti-rabbit immunoglobulin conjugated with fluorescein (Organon Teknika-Cappel), diluted $1: 1000$ in PBS-BSA. After a second wash with PBS-Tween, PBS containing $90 \%$ (v/v) glycerol was added, a coverslip was placed on the slide and the slide was examined by fluorescence microscopy for the presence of adherent bacteria.

(iii) Mucosal tissue homogenate adherence assay. For the standard assay, 96-well polystyrene microtitre plates (Becton Dickinson) were coated with $100 \mu \mathrm{l}$ homogenate in PBS-EDTA $(0.2 \mathrm{mg}$ protein $\mathrm{ml}^{-1}$ ) per well. Following overnight incubation at $4{ }^{\circ} \mathrm{C}$, the plates were drained, dried and fixed by incubating the plates at $60^{\circ} \mathrm{C}$ for $1 \mathrm{~h}$. Non-specific binding sites were blocked by incubating the homogenate-coated plates with $100 \mu \mathrm{l}$ PBS containing $3 \%(\mathrm{w} / \mathrm{v}) \mathrm{BSA}$ per well at $35^{\circ} \mathrm{C}$ for $1 \mathrm{~h}$, after which the plates were washed once with PBS. The bacterial suspension $(100 \mu \mathrm{l})$ was added to the wells and the plates were incubated at $35^{\circ} \mathrm{C}$ for $30 \mathrm{~min}$. Plates were then washed three times with PBS, and drained and fixed for $1 \mathrm{~h}$ at $60^{\circ} \mathrm{C}$. Primary antibody $(100 \mu \mathrm{l})$ diluted $1: 100$ in PBS containing 1\%(w/v) BSA and $0.5 \%$ (v/v) Tween 20 was added to each well and the plate was incubated at $35^{\circ} \mathrm{C}$ for $1 \mathrm{~h}$. The plate was washed three times with PBS-Tween. Anti-rabbit-immunoglobulin peroxidase conjugate $(100 \mu \mathrm{l})$ diluted $1: 1000$ or $1: 5000$, depending on the source, in PBS containing $1 \%(\mathrm{w} / \mathrm{v}) \mathrm{BSA}$ and $0.5 \%(\mathrm{v} / \mathrm{v})$ Tween 20 was added to each well and the plate was incubated at $35^{\circ} \mathrm{C}$ for $1 \mathrm{~h}$. The washing step was as described for the primary antibody. The binding was quantified by the addition of $100 \mu \mathrm{l}$ $o$-phenylenediamine $\left(0.12 \mathrm{mg} \mathrm{ml}^{-1}\right.$; Sigma) in peroxidase conjugate substrate buffer and incubation at room temperature for $30 \mathrm{~min}$. The reaction was stopped by adding $50 \mu \mathrm{l} 4 \mathrm{M} \mathrm{H}_{2} \mathrm{SO}_{4}$.
The $A_{450}$ was read in an ELISA reader (MR 700 Dynatech Laboratories). Controls consisted of wells not coated with homogenate for each strain tested, wells not reacted with bacteria, wells not reacted with bacteria or primary antibody, wells not reacted with homogenate or bacteria and wells not reacted with homogenate, bacteria or primary or secondary antibody. Except for the control without homogenate but reacted with bacteria, which consisted of three wells, all other controls consisted of six wells. Optical density readings for bacterial adherence were corrected for background by subtracting the mean of the optical density obtained for the control in which bacteria were not included. Statistical analysis was done using the Student's $t$ test.

To characterize the assay, different concentrations of homogenate and bacterial suspensions were examined. To test the effect of denaturing agents on adherence, homogenate $(0.2 \mathrm{mg}$ protein $\mathrm{ml}^{-1}$ ) was incubated at $35^{\circ} \mathrm{C}$ for $1 \mathrm{~h}$ in the presence of 2-mercaptoethanol at final concentrations of $9.6 \mathrm{mM}-4.8 \mathrm{M}$. The mercaptoethanol-treated homogenate was then used to coat microtitre plates as described above and adherence was examined.

\section{RESULTS}

\section{El Tor and classical biotypes of $V$. cholerae, but not non-motile derivatives, adhere to human epithelial cells}

By light microscopy, epithelial cells which had been prepared with a mesh screen or scraped from the mucosal surface, fixed to glass slides and stained with Gram stain, Giemsa or haematoxylin-eosin, exhibited normal morphology, i.e. a columnar shape, distinct cytoplasm and a darkly stained nucleus. For some of the Gram-stained cells, the apical region had a pink layer presumed to be mucus. Microvillar structures were also seen, in which case the pink layer was more prevalent. $V$. cholerae biotypes El Tor (N16961) and classical (395) grown on BHI agar adhered to the apical microvilli and basolateral cell membrane of individual epithelial cells and to the pink apical mucus layer covering cells (data not shown). Nonmotile aflagellate mutants KR26 (El Tor) and KR202 (classical) and non-motile flagellate mutants KR31 (El Tor) and KR201 (classical) did not adhere to epithelial cells. These mutants had previously been shown not to colonize in animal models (Richardson, 1991). E. coli strains HB101, HS (a normal flora non-motile isolate) and NF5 (a normal flora motile isolate) did not adhere to the epithelial cells.

\section{El Tor V. cholerae strain N16961 grown in LB or minimal A media does not adhere to epithelial cells}

The effect of growth medium on adherence to smears of epithelial cells was also examined. $V$. cholerae strain N16961 adhered best when grown on BHI agar or in broth and exhibited some adherence when grown on peptone medium agar or peptone/beef extract agar. No adherence was observed for strain N16961 grown on LB medium, minimal A medium or LB medium containing glucose. Mutant KR26, the non-motile derivative of strain N16961, and E. coli strain HB101 did not adhere when grown under any of these conditions. 

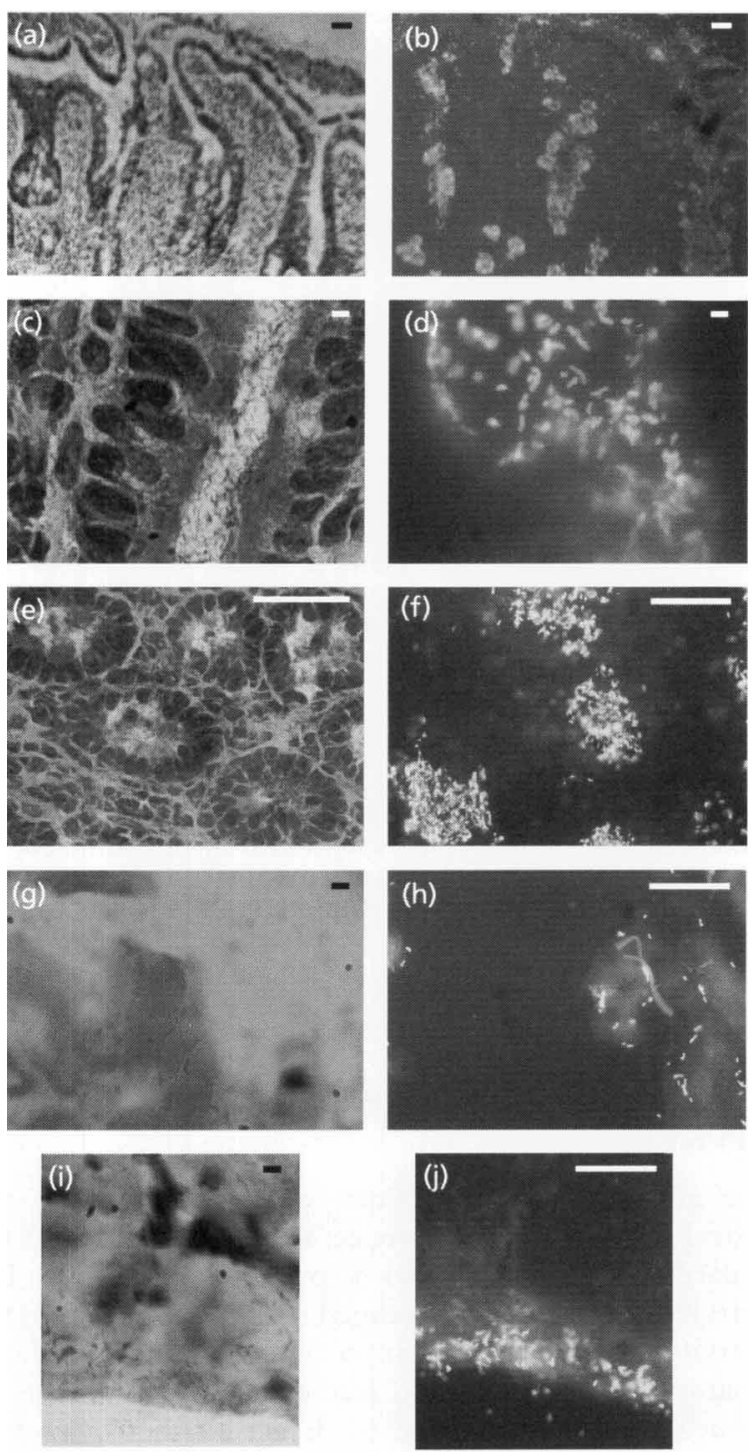

Fig. 1. Tissue sections of human small intestinal tissue reacted with $V$. cholerae strain 395 and either stained with haematoxylin-eosin $(a, c, e, g, i)$ or visualized by immunofluorescence microscopy following reaction with antibody $(b, d, f, h, j)$. ( $a, b) V$. cholerae adhering to the mucosal surface (bars, $10 \mu \mathrm{m})$. (c, d) The reaction of $V$. cholerae with the mucosal surface at higher magnification (bars, $1 \mu \mathrm{m}$ ). Bacteria are not seen adhering to internal structures of the epithelial cells. $(e, f) V$. cholerae adhering to the mucosal surface in the lymph space of epithelial tissue, but not to internal structures (bars, $10 \mu \mathrm{m})$. $(g, h)$ Very few bacteria are adhering to the submucosa (bars, 1 and $10 \mu \mathrm{m}$, respectively). (i, j) Bacteria are adhering to the serosal surface (bars, 1 and $10 \mu \mathrm{m}$, respectively).

\section{Adherence of $V$. cholerae to small intestinal tissue sections}

We were interested in developing an ELISA to quantitatively examine adherence. Therefore, to determine whether adherence was specific to the mucosa and the apical portion of the epithelial cells, we examined the location of bacterial adherence, using thin sections of both the entire small intestine and the dissected epithelial layer, by light microscopy and indirect immunofluorescence microscopy.

The sectioned tissue retained its normal morphology. Epithelial cells in sections from both dissected epithelium and intact small intestine were organized in a villar configuration, each with a lightly staining cytoplasm and dark-staining nucleus. In tissue sections of the entire small intestine, the underlying muscular tissue, blood vessels and smooth muscle could be distinguished beneath the mucus and the epithelial cell layer.

(i) V. cholerae strains $\mathrm{N16961}$ and 395 adhere to the apical mucosal surface of mucosal epithelial cells, while strain $\mathrm{C5}$ binds non-specifically to tissue sections and glass slides. The wild-type $V$. cholerae strains 395 and N16961 bound preferentially to the mucus layer, to the apical membrane of the epithelial cells and to epithelial cells lining lymph spaces as observed by staining and light microscopy. To a lesser extent, these $V$. cholerae strains also adhered to the smooth muscle layer and the serosal side of intact small intestine. By light microscopy, we could not observe any notable adherence of these $V$. cholerae strains to the intracellular structures of epithelial cells or to the basolateral membrane of dissected epithelial layers. $V$. cholerae strain C5, a field isolate from Indonesia, adhered nonspecifically to all parts of the tissue and to the glass slide. The normal flora E. coli strain HS was not observed to adhere to any part of the tissue except the smooth muscle layer. Non-motile flagellate $V$. cholerae mutants KR31 (El Tor) and KR201 (classical) and aflagellate mutants KR26 (El Tor) and KR202 (classical) did not bind to mucus, the epithelial cell layer or to connective tissue. Neither $V$. cholerae strain 395 nor strain N16961, when grown on LB medium agar, adhered to thin-sectioned tissue.

(ii) $V$. cholerae strains $\mathrm{N} 16961$ and 395 do not adhere to internal mucosal epithelial cell structures. To determine better whether vibrios were adhering to internal structures of the tissue sections, particularly the epithelial cell layer, we analysed tissue sections reacted with bacteria and examined by indirect immunofluorescence microscopy and then stained and examined by light microscopy. The sections did not take up the haematoxylin or eosin stains very well following indirect immunofluorescence microscopy and some of the more fragile mucosal epithelial cells were lost. Therefore, in Fig. 1, for comparison of vibrio adherence, the stained and immunofluorescent sections are not the same fields but corresponding regions of tissue sections visualized by each method. Control experiments were done with tissue alone to determine background reactivity and fluorescence. Epithelial cells lining blood vessels reacted strongly with fluorescent antibody, but could easily be distinguished from vibrios (Fig. 2).

Indirect immunofluorescence microscopy confirmed the results of the stained sections. Vibrios adhered preferentially to the apical regions of the mucosal epithelial cells (Fig. 1a-d), including those forming the mucosal lymph (Fig, 1e, f), without notable adherence to internal cell 

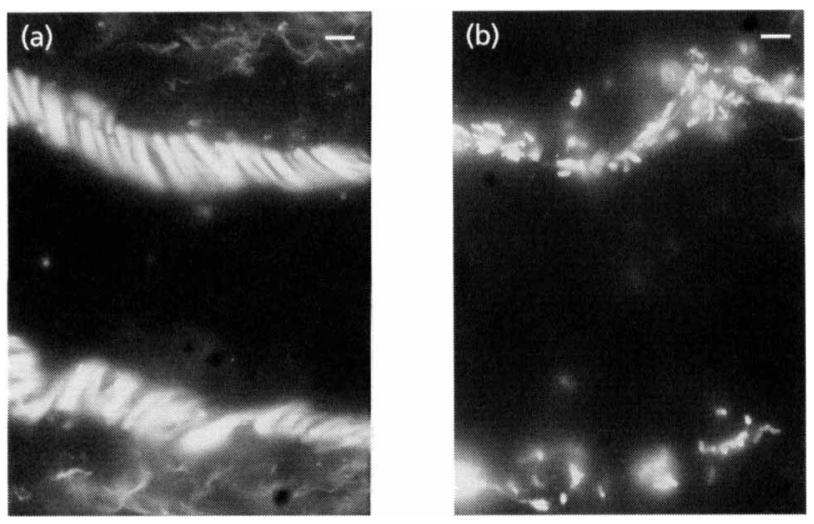

Fig. 2. Reaction of secondary goat anti-rabbit immunoglobulinfluorescein conjugate antibody with thin sections of small intestinal tissue only and thin-sectioned tissue reacted with bacteria prior to immunofluorescent visualization. Epithelial cells lining blood vessels reacted strongly with the fluorescent antibody (a), but were readily distinguished from bacteria adhering to the mucosal surface (b). Bacteria were reacted with tissue for $15 \mathrm{~min}$ at $35^{\circ} \mathrm{C}$. Bars, $1 \mu \mathrm{m}$.

structures or the underlying basolateral membrane of the dissected epithelial cell layer. Considerably fewer vibrios adhered to the submucosal structure underlying the mucosal epithelium (Fig. 1g, h) and a few adhered to the smooth muscle layer (data not shown). Considerable numbers of vibrios adhered to the serosal side of the small intestine (Fig. 1i, i). Very few E. coli cells (strains HS and HB101) were observed to adhere in a non-specific manner throughout the tissue (data not shown). Based on these results, an adherence assay was developed using the mucosal epithelial cell layer dissected away from the submucosa, musculature and serosal layer.

\section{ELISA for adherence of $V$. cholerae to homogenized small intestinal mucosa}

Several controls were done to test for non-specific binding, non-specific peroxidase activity, and antibody specificity for both primary and secondary antibodies. Mucosal homogenate and bacterial cells alone had no detectable peroxidase activity. Bacteria did not bind to microtitre plates except in the absence of the PBS-BSA blocking step. Primary antibody had no peroxidase activity and bound only to bacterial cells.

For this assay to be sensitive, it is essential that the primary antibody reacts well with all the strains of $V$. cholerae examined. To determine the sensitivity of primary antiserum for detecting bacteria, antibody reactivity with bacteria was examined in a checkerboard experiment. Antibody to $V$. cholerae strain KR26, a derivative of strain N16961, was examined. The reactivity of other N16961 derivatives and $\mathrm{El}$ Tor strains with this antiserum ranged from 85 to $150 \%$ of the reactivity with the homologous strain. Antiserum to strain KR26 also reacted very well with the heterologous classical strain 395 , its derivatives and strain C21. Reactivity with the heterologous strains

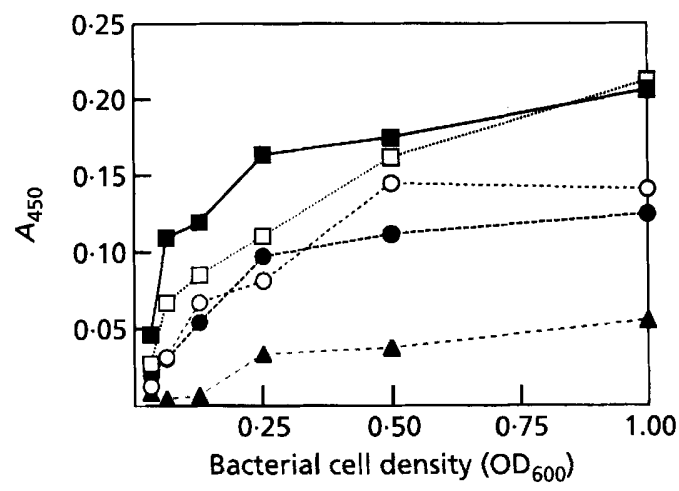

Fig. 3. Checkerboard experiment to determine optimal cell homogenate concentration and bacterial concentration. Microtitre wells were coated with varying concentrations of epithelial cell homogenate $\left(7.8 \mu \mathrm{g}-1 \mathrm{mg}\right.$ protein $\left.\mathrm{ml}^{-1}\right)$ in one dimension and reacted with various concentrations of bacteria $\left(O D_{600} 0.03-1.0\right)$ in the other dimension for $30 \mathrm{~min}$ at $35^{\circ} \mathrm{C}$. The binding of bacteria was detected by ELISA using primary rabbit antiserum raised against the bacteria and secondary antibody of goat anti-rabbit immunoglobulin conjugated with peroxidase. Adherence was quantitatively determined by reading the $A_{450}$. The absorbance was then plotted as a function of the bacterial concentration. Protein concentrations of homogenate tested were: $7.8 \mu \mathrm{g} \mathrm{ml}^{-1}(\boldsymbol{\Delta}) ; 31 \mu \mathrm{g} \mathrm{ml}^{-1}(\boldsymbol{O})$; $125 \mu \mathrm{g} \mathrm{ml}^{-1}(O) ; 250 \mu \mathrm{g} \mathrm{ml}^{-1}(\square)$; and $1 \mathrm{mg} \mathrm{ml}^{-1}$ (D).

was equal to, or twofold greater than, reactivity with strain KR26.

Since all the classical isolates were compared to the classical strain 395 for adherence, we used this strain as the standard for reactivity with primary antibody. The reactivity of these isolates ranged from 60 to $122 \%$ of the reactivity observed with strain 395 . Since the antibody preparation to strain KR26 reacted well with all the $V$. cholerae strains, it was used to detect all the $V$. cholerae isolates in the adherence assays. Primary antiserum used to detect the E. coli strains was raised against E. coli strain HB101. The E. coli strains LE392, HS and NF5 exhibited antibody reactivities within $25-50 \%$ of each other.

Finally, we screened several preparations of secondary antibody for specificity. We observed that some secondary antibody preparations exhibited relatively high nonspecific reactivity with homogenized tissue alone. Secondary antibody which bound only in the presence of primary antibody was selected for use.

(i) A bacterial density of $O D_{600} 1 \cdot 0$ and homogenate concentration of $1.0 \mathrm{mg}$ protein $\mathrm{ml}^{-1}$ are optimal for the adherence assay with $\boldsymbol{V}$. cholerae El Tor strain N16961. To determine the optimal concentrations of homogenate and bacteria, a checkerboard experiment was done varying the concentration of homogenate in one dimension and the bacterial cell concentration in the other dimension. Optimal binding of strain N16961 occurred at a bacterial density of $1.0\left(\mathrm{OD}_{600}\right)$ and a cell homogenate concentration of $0 \cdot 25-1.0 \mathrm{mg}$ protein $\mathrm{ml}^{-1}$ (Fig. 3).

(ii) Maximum adherence for $V$. cholerae El Tor strain N16961 occurs within $\mathbf{3 0} \mathrm{min}$. The effect of incubation time on 


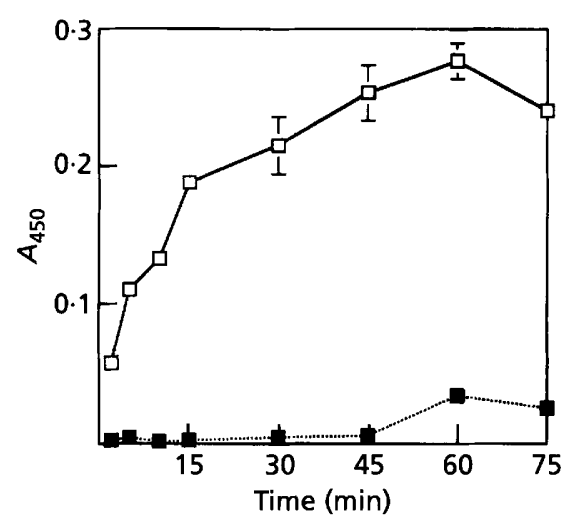

Fig. 4. Optimal reaction time of bacteria with epithelial cell homogenate. Binding of the wild-type strain N16961 ( $\square$ ) and the non-motile, flagellate derivative KR31 ( $\square$ ) was detected by ELISA using primary rabbit antiserum raised against the bacteria and secondary antibody of goat anti-rabbit immunoglobulin conjugated with peroxidase. Adherence was quantitatively determined by reading the $A_{450}$ and plotted as a function of time.

binding was examined over a period of 75 min. Halfmaximal binding with strain N16961 was reached after 5 min incubation (Fig. 4) and the adherence reached a plateau after $30 \mathrm{~min}$ incubation. The non-motile flagellate mutant KR31 was tested and no binding was observed, even after $75 \mathrm{~min}$ incubation (Fig. 4).

(iii) No loss of adherence can be detected after storage of homogenized tissue at -20 to $-180^{\circ} \mathrm{C}$ for up to 3 months.

To examine the effect of storage temperature and storage time on adherence of bacteria to homogenized smallbowel epithelial tissue, homogenate was stored at -20 , -70 and $-180^{\circ} \mathrm{C}$ and after 3 and 5 months, adherence of wild-type $V$. cholerae strain N16961 and the non-motile mutants KR31 and KR201 was examined by the standard assay. With homogenized tissue, adherence was detected longer with colder storage. Homogenized tissue stored for 3 months at $-20,-70$ and $-180^{\circ} \mathrm{C}$ was as receptive to adherence as freshly homogenized tissue, but when stored for 5 months at $-20,-70$ and $-180^{\circ} \mathrm{C}$ adherence of strain N16961 was significantly reduced by 34,43 and $56 \%$, respectively (Student's $t$ test). The non-motile mutants KR31 and KR201 exhibited negligible adherence to homogenate, regardless of the duration of storage (data not shown).

(iv) $V$. cholerae and $E$. coli strains adhere poorly to homogenized mucosal epithelial cells from the caecum. The adherence of $V$. cholerae wild-type and mutant strains and of $E$. coli strains to homogenized epithelial tissue from the small intestine was compared to adherence to homogenized epithelial tissue from the caecum to further examine the specificity of adherence of $V$. cholerae. $V$.

Table 2. Adherence of $V$. cholerae and $E$. coli to human small intestinal mucosa homogenate

\begin{tabular}{|c|c|c|c|}
\hline Strain & Characteristics & Absorbance $\pm S D^{*}$ & $P$ value $\dagger$ \\
\hline \multicolumn{4}{|c|}{ E1 Tor biotype vibrios } \\
\hline N16961 & Wild-type & $0 \cdot 375 \pm 0 \cdot 090$ & \\
\hline KR518 & Wild-type, Tn 10 mini-Kan & $0.396 \pm 0.040$ & $0 \cdot 45$ \\
\hline KR26 & Non-motile, aflagellate & $0 \cdot 040 \pm 0 \cdot 029$ & $<0.001$ \\
\hline KR31 & Non-motile, flagellate & $0 \cdot 008 \pm 0 \cdot 009$ & $<0.001$ \\
\hline SB001 & Haemagglutinin mutant & $0 \cdot 310 \pm 0 \cdot 038$ & $0 \cdot 012$ \\
\hline $\mathrm{C} 5$ & Wild-type & $0 \cdot 490 \pm 0 \cdot 033$ & $<0.001$ \\
\hline $1074-78$ & Cholera toxin mutant & $0 \cdot 398 \pm 0 \cdot 071$ & $0 \cdot 36$ \\
\hline $1196-78$ & Cholera toxin mutant & $0.482 \pm 0.060$ & $<0.001$ \\
\hline \multicolumn{4}{|c|}{ Classical biotype vibrios } \\
\hline 395 & Wild-type & $0 \cdot 212 \pm 0 \cdot 125$ & \\
\hline KR201 & Non-motile, flagellate & $0 \cdot 008 \pm 0.009$ & $<0.001$ \\
\hline KR202 & Non-motile, aflagellate & $0.073 \pm 0.029$ & $<0.001$ \\
\hline KR1 & Non-motile, aflagellate, sheathed & $0 \cdot 069 \pm 0 \cdot 018$ & $<0.001$ \\
\hline 395.2 & Neuraminidase mutant & $0 \cdot 316 \pm 0 \cdot 076$ & $>0 \cdot 001$ \\
\hline $\mathrm{C} 21$ & Non-motile, haemagglutinin-negative & $0 \cdot 003 \pm 0 \cdot 005$ & $<0.001$ \\
\hline \multicolumn{4}{|l|}{ E. coli } \\
\hline NF5 & Motile, normal flora isolate & $0 \cdot 067 \pm 0 \cdot 031$ & \\
\hline HS & Non-motile, normal flora isolate & $0.004 \pm 0.010$ & $<0 \cdot 001$ \\
\hline LE392 & Non-motile laboratory strain & $0.003 \pm 0.006$ & $<0.001$ \\
\hline
\end{tabular}

* $A_{450}$ of modified ELISA. Values are the means of at least three experiments, except for strains KR518, SB001 and KR1, which were examined in two experiments. Each experiment was done with three to six wells for each strain.

† Statistical comparisons by Student's $t$ test. 


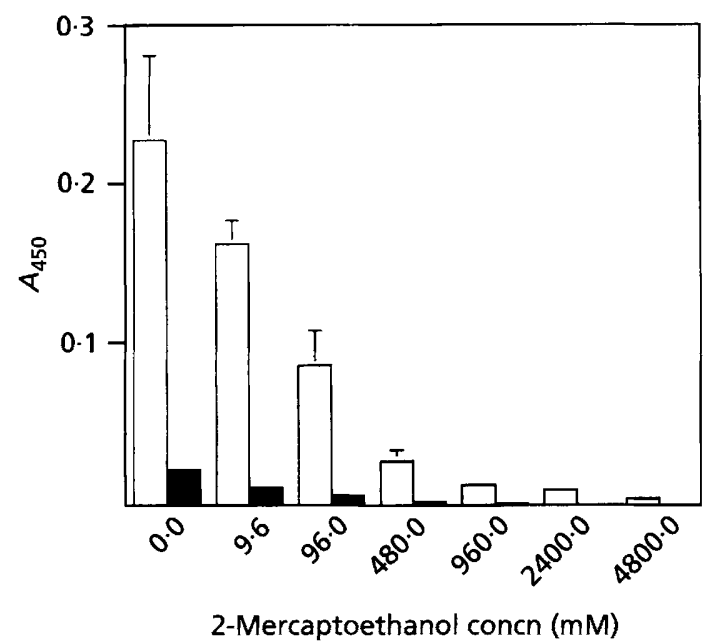

Fig. 5. Effect of 2-mercaptoethanol treatment of epithelial cell homogenate on binding of $V$. cholerae. Homogenate was incubated with 2-mercaptoethanol for $1 \mathrm{~h}$ at $35^{\circ} \mathrm{C}$ and then used to coat microtitre wells. Binding of the wild-type strain N16961 (open bars) and the non-motile, flagellate derivative KR31 (solid bars) was detected by ELISA using primary rabbit antiserum raised against the bacteria and secondary antibody of goat anti-rabbit immunoglobulin conjugated with peroxidase. Adherence was quantitatively determined by reading the $A_{450}$ and plotted as a function of the concentration of 2-mercaptoethanol used to treat the cell homogenate.

cholerae does not normally adhere to epithelial tissue in the caecum. All of the strains tested for adherence exhibited significantly reduced adherence to homogenized caecum epithelial tissue (Student's $t$ test). Adherence was reduced by $58-89 \%$, with the adherence of most strains reduced about $75 \%$ (data not shown).

(v) Motility mutants of classical and El Tor V. cholerae exhibit significantly reduced adherence in the ELISA. Wild-type strains, transposon-insertion mutants and spontaneous mutants were tested for adherence. Wild-type strains of El Tor and classical isolates adhered to the homogenate. Wild-type strain C5 (El Tor, Ogawa) exhibited the greatest adherence with an $A_{450}$ approximately twofold greater than with strain N16961 (biotype El Tor) or strain 395 (classical, Ogawa) (Table 2). The non-enterotoxigenic Brazilian strains 1196-78 and 1074-78 (El Tor, Ogawa) exhibited absorbance values as high as with the $\mathrm{C} 5$ strain. The non-motile flagellate mutant KR31 and the nonmotile aflagellate mutant KR26 exhibited considerably lower binding to homogenate, compared with strain N16961 (Table 2). The haemagglutinin-negative derivative SB001 of strain N16961 exhibited slightly less adherence than the parental strain N16961. Both mutants KR1 and KR202, non-motile mutant derivatives of classical strain 395, adhered to some extent, though considerably less than the parental strain. However, a non-motile flagellate mutant, KR201, also a derivative of strain 395, did not adhere. The neuraminidase-negative mutant 395.2 adhered as well as the wild-type parent strain.
The adherence of five putative chemotaxis mutants, isolated following insertional mutagenesis with $\operatorname{Tn} 10$ mini-Kan (unpublished results), was examined because of the importance of motility for colonization and the observation that non-motile mutants did not adhere in the modified ELISA system. The mutants used in this assay were presumed to be chemotaxis mutants based on the criteria that they form pinpoint colonies in soft agar and exhibit motility in broth cultures observed by light microscopy. All of the five mutants examined exhibited significantly reduced adherence $(P<0 \cdot 001), 5-23 \%$ of the adherence of the parental strain N16961 (data not shown).

All of the E. coli strains examined adhered poorly (Table 2 ). Interestingly, the only isolate that exhibited any adherence at all was the motile normal flora isolate NF5. The other two isolates, HS and LE392, were non-motile.

(vi) Treatment of homogenate with mercaptoethanol abolishes adherence by $\boldsymbol{V}$. cholerae strain $\mathbf{N 1 6 9 6 1}$. To begin the characterization of epithelial cell components involved in the adherence of $V$. cholerae, the homogenate was treated with different concentrations of mercaptoethanol before it was used to coat the microtitre plates. Concentrations as low as $9.6 \mathrm{mM}$ mercaptoethanol were sufficient to reduce binding of $V$. cholerae strain N16961 to the homogenate, while $0.96 \mathrm{M}$ mercaptoethanol completely abolished binding (Fig. 5).

\section{DISCUSSION}

Humans are the only known natural hosts for $V$. cholerae infection. Vibrios only colonize the small intestine. Therefore, colonization studies using animal tissues from rabbits and mice may not identify the factors important for colonization of human small intestine by $V$. cholerae. We have developed an in vitro adherence assay that uses human small intestinal mucosa, the tissue layer directly involved in colonization by $V$. cholerae, to approximate the environment of the natural host. We were able to observe the same specificity of binding to homogenized tissue as was observed with isolated mucosal epithelial cells and thin-sectioned small intestinal tissue. Wild-type $V$. cholerae strains bound to human small intestine homogenate, whereas non-motile mutants exhibited no, or greatly reduced, adherence.

The assay provides a method to analyse adherence in a quantitative manner that is readily accessible to researchers. The use of homogenized small intestinal epithelial cells requires less tissue to coat microtitre wells and, hence, conserves a relatively precious and rare resource. The ability to use microtitre plates provides an opportunity to perform numerous assays, including screening mutagenized bacteria or gene libraries. We observed no adherence (data not shown) in a preliminary screen of a library of $V$. cholerae strain N16961 genomic DNA in the $E$. coli host HB101. Since non-motile $V$. cholerae and non-motile $E$. coli exhibited significantly reduced adherence in this assay, it may be necessary to produce the gene libraries in host strains that are motile. 
A critical factor in the assay is the use of secondary antibody. Control experiments revealed that secondary antibody from several suppliers bound to tissue in the absence of bacteria. Hence, examination for non-specific binding of secondary antibody to tissue in the absence of bacteria is an essential control.

Although the specific epithelial cell factors involved in $V$. cholerae binding are unknown, our observations and those of others (Yamamoto \& Yokota, 1988) indicate that mucus plays a role. Mucus is a multimeric glycoprotein structure with secondary and tertiary conformation. The polymeric structure of the mucus gel is destroyed by reduction with mercaptoethanol (Sellers et al., 1988). The loss of adherence of bacteria to homogenate treated with mercaptoethanol suggests that the adherence assay is able to evaluate binding due to mucin as well as indicating that the secondary and tertiary structures of glycoproteins in the mucus layer or cell membrane proteins are important for bacterial binding.

The ELISA with homogenized small intestinal epithelial cells allowed us to examine and quantify the binding capacity of a variety of $V$. cholerae strains of both biotypes. $V$. cholerae strains with mutations in motility and flagellar genes exhibited no adherence to isolated epithelial cells. However, in the ELISA, while all the non-motile mutants were observed to have significantly reduced adherence, some isolates, viz. KR26, KR202 and KR1, did exhibit some adherence. Two possible explanations are that (i) motility may enable vibrios to reach the receptor target or (ii) gene expression of motility may be linked to expression of adherence factors. The observation that presumptive chemotaxis mutants also exhibited reduced adherence further supports the conclusion that factors involved in motility are important for adherence. These results corroborate previous reports of $V$. cholerae adherence to human intestinal epithelial cell membranes and the mucus layer (Yamamoto \& Yokota, 1988) and to rabbit and mouse epithelial cells isolated from the small intestine (Jones et al., 1976; Attridge \& Rowley, 1983).

Wild-type El Tor strain N16961 and two Brazilian nonenterotoxigenic strains, $1074-78$ and 1196-78, were able to bind to homogenate. This contrasts with the observations in volunteers, who were only poorly colonized with these two isolates (Levine et al., 1982). Colonization is undoubtedly a multifactorial process and the adherence of these strains in this in vitro assay may prove useful in identifying factors involved in colonization by comparing adherence in vitro and in vivo. It is possible that the peristaltic activity of the small intestine, which is believed to be important in protecting against colonization, might be a factor involved in the failure of these two isolates to colonize the small intestine in volunteers, yet exhibit adherence in vitro.

The haemagglutinin-negative mutant SB001, a Tn5 insertion mutant derivative of strain N16961, did not exhibit substantially reduced adherence in this assay but did exhibit reduced colonization in at least one rabbit model (Finn et al., 1987). A possible explanation for this apparent discrepancy is that wild-type $V$. cholerae does not colonize well in the animal models, presumably due to the absence of adherence mechanisms. Therefore, a mutant which does not colonize well in an animal model might still adhere to human tissue by mechanisms not available in animal small bowel tissue.

Wild-type 395 (classical) and an isogenic neuraminidasenegative mutant strain bound equally well to homogenate. This result suggests that neuraminidase is not important for binding to intestinal mucosa. Galen et al. (1992) observed in animal models that neuraminidase appeared to play a role in increasing the activity of cholera toxin by increasing the availability of receptors, but did not appear to play a direct role in colonization.

The El Tor strain C5, originally isolated in Indonesia, adhered non-specifically, including adherence to glass slides. Various $V$. cholerae isolates exhibit adherence to a number of different substrates, including chitin, glass, $\mathrm{CaCO}_{3}$ particles, water hyacinth roots and the solid matrix of water filters (Colwell \& Spira, 1992).

In conclusion, we have developed a quantitative and efficient assay to characterize colonization and adherence factors of $V$. cholerae. The assay should be a useful tool to elucidate the molecular basis of adherence and also to characterize at the genetic level the genes involved in the process.

\section{ACKNOWLEDGEMENTS}

We thank the Departments of Surgery and Surgical Pathology of the Oregon Health Sciences University, the Department of Surgical Pathology of Providence Hospital, and the Pacific Northwest Transplant Bank at Oregon Health Sciences University for the specimens of human small intestine, Christine Kowalzkc for her technical help, and Dr Bill Wolfgang and especially George Cole for their help with the frozen sections. This work was supported in part by the Tartar Trust Fellowship 1989 from the Oregon Health Sciences University, by Public Health Service grant AI23417 from the National Institute of Allergy and Infectious Diseases, and the Oregon Medical Research Foundation.

\section{REFERENCES}

Attridge, S. R. \& Rowley, D. (1983). The specificity of Vibrio cholerae adherence and the significance of the slime agglutinin as a second mediator of in vitro attachment. I Infect Dis 147, 873-881.

Baselski, V., Briggs, R. \& Parker, C. (1977). Intestinal fluid accumulation induced by oral challenge with $V$ ibrio cholerae toxin in infant mice. Infect Immun 15, 704-712.

Blake, P. A., Snyder, J. D., Barret, T. J., McFarland, L., Caraway, C. T., Feeley, J. C., Craig, J. P., Lee, J. V., Puhr, N. D. \& Feldman, R. A. (1980). Cholera - a possible endemic focus in the United States. $N$ Engl I Med 302, 305-309.

Boyer, H. W. \& Rouland-Dussoix, D. (1969). A complementation analysis of the restriction and modification of DNA in Liscberichia coli. J Mol Biol 41, 459-472.

Chitnis, D. S., Sharma, K. D. \& Kamat, R. S. (1982). Role of somatic antigen of $V$ ibrio cholerae in adhesion to intestinal mucosa. $J \mathrm{Med}$ Microbiol 5, 53-61. 
Colwell, R. R. \& Spira, W. M. (1992). The ecology of Vibrio cholerae. In Cholera, pp. 106-127. Edited by D. Barua \& W. B. Greenough, III. New York: Plenum Medical Book Company.

De, S. N. \& Chatterjee, D. N. (1953). An experimental study of the mechanism of action of Vibrio cholerae on the intestinal mucous membrane. J Pathol Bacteriol 66, 559-562.

Finkelstein, R. A., Boseman-Finkelstein, M., Chang, Y. \& Hase, C. C. (1992). Vibrio cholerae hemagglutinin/protease, colonial variation, virulence, and detachment. Infect Immun 60, 472-478.

Finn, T. M., Reiser, J., Germanier, R. \& Cruz, S. J., Jr (1987). Cellassociated hemagglutinin-deficient mutant of Vibrio cholerae. Infect Immun 55, 942 -946.

Franzon, V. F., Barker, A. \& Manning, P. A. (1993). Nucleotide sequence and the construction of a mutant in the mannose-fucoseresistant hemagglutinin (MRFRHA) of Vibrio cholerae O1. Infect Immun 61, 3032-3037.

Freter, R. \& Jones, G. W. (1983). Models for studying the role of bacterial attachment in virulence and pathogenesis. Rev Infect Dis (Suppl. 4) 5, S647-S658.

Freter, R., O'Brien, P. C. M. \& Macsai, M. S. (1981). Role of chemotaxis in the association of motile bacteria with intestinal mucosa: in vivo studies. Infect Immun 34, 234-240.

Galen, J. E., Ketley, J. M., Fasano, A., Richardson, S. H., Wasserman, S. S. \& Kaper, J. B. (1992). Role of Vibrio cholerae neuraminidase in the function of cholera toxin. Infect Immun 60, 406-415.

Gill, M. D. (1977). Mechanisms of action of cholera toxin. Adv Cyclic Nucleotide Res 8, 85-118.

Guentzel, M. N. \& Berry, L. J. (1975). Motility as a virulence factor for Vibrio cholerae. Infect Immun 11, 890-897.

Herrington, D. A., Hall, R. A., Losonsky, G., Mekalanos, J. J., Taylor, R. K. \& Levine, M. M. (1988). Toxin, toxin-coregulated pili and tox $\mathrm{R}$ regulon are essential for Vibrio cholerae pathogenesis in humans. J Exp Med 168, 1487-1492.

Jones, G. W. \& Freter, R. (1976). Adhesive properties of Vibrio cholerae: nature of the interaction with isolated rabbit brush border membranes and human erythrocytes. Infect Immun 14, 240-245.

Jones, G. W., Abrams, G. D. \& Freter, R. (1976). Adhesive properties of Vibrio cholerae: adhesion to isolated rabbit brush border membranes and hemagglutinating activity. Infect Immun 14, 232-239.

Kelley, J. T. \& Parker, C. D. (1981). Identification of Vibrio cholerae outer membrane proteins. J Bacteriol 145, 1018-1024.

Levine, M. M. \& Edelman, R. E. (1979). Acute diartheal infections in infants. I. Epidemiology, treatment and immunoprophylaxis. Hosp Pract 14, 89-100.

Levine, M. M., Black, R. E., Clements, M. L., Cisneros, L., Saah, A., Nalin, D. R., Gill, D. M., Craig, J. P., Young, C. R. \& Ristaino, P. (1982). The pathogenicity of nonenterotoxigenic Vibrio cholera serogroup O1 biotype El Tor isolated from sewage water in Brazil. J Infect Dis 145, 296-299.

Levine, M. M., Kaper, J. B., Black, R. E. \& Clements, M. L. (1983). New knowledge on pathogenesis of bacterial enteric infections as applied to vaccine development. Microbiol Rev 47, 510-550.

Miller, J. H. (1972). Experiments in Molecular Genetics, pp. 432-433. Cold Spring Harbor, NY: Cold Spring Harbor Laboratory.
Murray, N. E., Brammar, W. J. \& Murray, K. (1977). Lambdoid phages that simplify recovery of in vitro recombinants. Mol Gen Genet 150, 53-61.

Parker, C. \& Romig, W. R. (1972). Self transfer and genetic recombination mediated by $\mathrm{P}$, the sex factor of Vibrio cholerae. J Bacteriol 112, 707-714.

Richardson, K. (1991). Roles of motility and flagellar structure in pathogenicity of Vibrio cholerae: analysis of motility mutants in three animal models. Infect Immun 59, 2727-2736.

Richardson, S. H. (1994). Animal models in cholera research. In Vibrio cholerae and Cholera: Molecular to Global Perspectives, pp. 203-226. Edited by I. K. Wachsmuth, P. A. Blake \& Ø. Olsvik. Washington, DC: American Society for Microbiology.

Richardson, K., Nixon, L., Mostow, P., Kaper, J. B. \& Michalski, J. (1990). Transposon-induced non-motile mutants of Vibrio cholerae. $J$ Gen Microbiol 136, 717-725.

Sack, R. B. (1992). Colonization and pathology. In Cholera, pp. 189-197. Edited by D. Barua \& W. B. Greenough, III. New York: Plenum Medical Book Company.

Sears, S. D., Richardson, K., Young, C., Parker, C. D. \& Levine, M. M. (1984). Evaluation of the human immune response to outer membrane protein of Vibrio cholerae. Infect Immun 44, 339-344.

Sellers, L. A., Allen, A., Morris, E. R. \& Ross-Murphy, S. B. (1988). Mucus glycoprotein gels, role of glycoprotein polymeric structure and carbohydrate side-chains in gel-formation. Carbohydr Res 178, 93-110.

Singh, S. N., Srivastava, R., Sinha, V. B. \& Srivastava, B. S. (1994). A $53 \mathrm{kDa}$ protein of Vibrio cholerae classical strain 0395 involved in intestinal colonization. Micrab Pathog 17, 69-78.

Sperandio, V., Giron, J. A., Silveira, W. D. \& Kaper, J. B. (1995). The OmpU outer membrane protein, a potential adherence factor of Vibrio cholerae. Infect Immun 63, 4433-4438.

Spira, W. M., Sack, R. B. \& Froehlich, J. L. (1981). Simple adult rabbit model for Vibrio cholerae and enterotoxigenic Escherichia coli diarthea. Infect Immun 32, 739-747.

Srivastava, R., Shinha, V. B. \& Srivastava, B. S. (1980). Events in the pathogenesis of experimental cholera: role of bacterial adherence and multiplication. J Med Microbiol 13, 1-9.

Sun, D., Mekalanos, J. J. \& Taylor, R. K. (1990). Antibodies directed against the toxin-coregulated pilus isolated from Vibrio cholerae provide protection in the infant mouse experimental cholera model. $J$ Infect Dis 161, 1232-1236.

Teppema, J. S., Guinee, P. A. M., Ibrahim, A. A., Paques, M. \& Ruitenberg, E. J. (1987). In vivo adherence and colonization of Vibrio cholerae strains that differ in hemagglutinin activity and motility. Infect Immun 55, 2093-2102.

Yamamoto, T. \& Yokota, T. (1988). Electron microscopic study of $V$ ibrio cholerae $\mathrm{O} 1$ adherence to the mucus coat and villi surface in the human small intestine. Infect Immun 56, 2753-2759.

Yang, G. C. H., Schrank, G. D. \& Freeman, B. A. (1977). Purification of flagellar cores of Vibrio cholerae. J Bacteriol 129, 1121-1128.

Received 4 January 1996; revised 27 June 1996; accepted 5 July 1996 